\title{
Three Modes of Rhetorical Persuasion
}

\author{
WANG Lin \\ University of Shanghai for Science and Technology, Shanghai, China
}

\begin{abstract}
Rhetoric originates in public speeches and in turn guides public speeches; public speeches embody the essential nature of rhetoric-persuasion. This thesis takes practical instances of political speeches to study the rhetoric of persuasion with particular attention to the three modes as tactics of persuasion commonly designed or employed in political speeches.
\end{abstract}

Keywords: logos, ethos, pathos, persuasion

\section{Introduction}

Rhetoric is an art of speaking, mainly persuading according to Aristotle.

In Book I, Chapter 2 of Rhetoric, Aristotle identifies three technical or artistic proofs (ethos, pathos, and logos) that make up the art of rhetoric. He takes logos, pathos, and ethos as the three modes of persuasion. Ethos, persuasion through convincing listeners of one's moral competence, names the persuasive appeal of one's character, especially how this character is established by means of the speech or discourse. Pathos, persuasion by means of emotional appeal, names the appeal to emotion, and logos, which makes the speaker look prepared and knowledgeable to the audience, names the appeal to reason. (Herrick, 1997, pp. 81-83)

\section{Logos as Persuasive Tactic in Speeches}

Public discourse on ancient Greek rhetoric has historically emphasized Aristotle's appeals to logos, pathos, and ethos, while less attention has been directed to Isocrates' teachings about philosophy and logos. Isocrates (470-399 BC) studies philosophy and logos. He does not provide a single definition of logos in his work, but Isocrates' logos characteristically focus on speech, reason, and civic discourse (Timmerman \& Schiappa, 2010, pp. 43-66). He was concerned with establishing the "common good" of Athenian citizens, which he believed could be achieved through the pursuit of philosophy and the application of logos (Timmerman \& Schiappa, 2010, pp. 43-66).

According to Aristotle (384-322 BC), logos relates to "the speech itself, in so far as it proves or seems to prove" (Aristotle, 1990, p. 120). The persuasive mode logos are also called "rational appeal". It means creating a sense of reasoning, either inductive or deductive, in the audience and allowing them to make the logical connections in the speech. Logos appeal includes appeals to statistics, math, logic, and objectivity. Inductive reasoning uses examples (historical, mythical, or hypothetical) to draw conclusions. Deductive or enthymematic reasoning uses generally accepted propositions to derive specific conclusions. The term logic evolved from logos. Aristotle emphasizes enthymematic reasoning as central to the process of rhetorical invention.

WANG Lin, Doctor's degree, associate professor, College of Foreign Languages, University of Shanghai for Science and Technology, Shanghai, China. 
What Aristotle rejects in supporting the use of logos

is not emotional appeal per se, but rather emotional appeals that have no 'bearing on the issue', in that the pathē [ $\pi$ ă $\theta \eta$, páthē] they stimulate lack, or at any rate are not shown to possess, any intrinsic connection with the point at issue-as if an advocate were to try to whip an antisemitic audience into a fury because the accused is Jewish; or as if another in drumming up support for a politician were to exploit his listeners' reverential feelings for the politician's ancestors. (Wardy, 1996, p. 64)

For logos, that means speakers not only present the information objectively but also present both sides of an argument.

In the famous speech "On the Nazi Invasion of the Soviet Union", Winston Churchill's logos proceed with a combination force of enthymeme:

Any man or state who fights on against Nazidom will have our aid.

Any man or state who matches with Hitler is our foe...

It follows therefore that we shall give whatever help we can to Russian and Russian people.

The first two sentences are major premise (the minor premise "Russian fights against Nazidom" is omitted here), the third sentence is the conclusion. Here "It follows" means "It can be concluded from", used to inducing the deduction.

At the end of the speech, Churchill analyzes Hitler's tactic intentions, namely, to end the military assault to the Soviet Union as soon as possible, and to attack British islands with all military forces. Therefore, Churchill goes on deducing,

The Russian danger is therefore our danger, and the danger of the United States, just as the cause of any Russian man fighting for his hearth and home is the cause of free men and free peoples in every quarter of the globe. (Churchill, "On the Nazi Invasion of the Soviet Union”, 1941)

\section{Pathos as Persuasive Tactic in Speeches}

Pathos can be called "emotional appeal", passion suffered or persuading by appealing to the audience's emotions. It is an appeal to the audience's sense of identity, self-interest, and emotions. Though human beings are a rational being by nature, they will always be promoted or pushed by their emotions. Pathos attempts to stir up some negative or positive emotion that will motivate audience. According to Aristotle, the effect of emotional appeal includes moral anger, ambition, excitement, fear, happiness, pity, jealousy, and other feelings. Communicators have worked with fear, guilt, and shame appeals in getting people to do things they should or stop doing things they should not. Communicators also use positive emotional appeals, such as love, humor, pride, and joy. It requires speakers to first establish a trusting relationship with the prospect.

In "Rhetoric", Aristotle identifies pathos as "awakening emotion (pathos) in the audience so as to induce them to make the judgment desired" (Aristotle \& Kennedy, 1991, p. 119). But the concept of emotional appeal existed in rhetoric long before Aristotle's "Rhetoric". Gorgias (483-375 BC), an ancient Greek sophist, pre-Socratic philosopher, and rhetorician, holds great interests in orators' emotional appeal as well. Gorgias believes speakers are able to capture and lead audience in any direction they please by emotional appeal. People's soul can feel a particular sentiment on account of words, such as sorrow and pity. And certain words act as "bringers-on of pleasure and takers-off of pain". Plato, who also precedes Aristotle, discusses emotional appeal from the perspective of rhetoric. In his dialogue "Gorgias", Plato discusses pleasure versus pain in the 
realm of pathos though in a fictional conversation between Gorgias and Socrates. The dialogue between several ancient rhetors that Plato created centers around the value of rhetoric, and the men incorporate aspects of pathos in their responses. Gorgias discredits pathos and instead promotes the use of ethos in persuasion. Plato argues emotional appeal in rhetoric should be used as the means to an end and not the point of the discussion.

Gorgias and Plato, like other sophists, lay the groundwork of pathos, while Aristotle theorizes the concept of pathos. Aristotle defines pathos as one of the three essential modes of proof used by speakers "to understand the emotions - that is, to name them and describe them, to know their causes and the way in which they are excited (Aristotle \& Kennedy, 1991, p. 119), since audience would change their opinion or idea in regard to their own judgment when listening. Besides the deploying of good ethos to establish credibility, it is emotion that produces specific causes and effects in this process of changing.

Aristotle focuses on whom, toward whom, and why to decide which specific emotion speakers would exhibit or call upon in order to persuade audience. Aristotle's theory of pathos contains three main foci, the frame of mind the audience is in, the variation of emotion between people, and the influence the rhetor has on the emotions of the audience. Aristotle classifies the third of this trio as the ultimate goal of pathos (Aristotle, Bizzell, \& Herzberg, 2001). Similarly, Aristotle outlines the individual importance of persuasive emotions, as well as the combined effectiveness of these emotions on the audience. Moreover, Aristotle pointedly discusses pleasure and pain in relation to the reactions these two emotions cause in an audience member. According to Aristotle, emotions vary from person to person. Therefore, he stresses the importance of understanding specific social situations in order to successfully utilize pathos as a mode of persuasion. Aristotle takes the introduction and the conclusion as the most important two places for an emotional appeal in any persuasive argument.

Pathos is the emotion that you use, but do not use manipulatively. Speakers are for being persuasive, they are convincing their readers through the words and the evidence that speakers provide. Pathos or the most part of pathos is psychological description and that entails the usage of speakers' five senses, which means audience can visualize what speakers are presenting. That is, audience can see, can touch, and can taste. This emotional appeal can be achieved by using psychological description. However, when using emotion and psychological description, speakers should be very careful in case it goes beyond convincing. Providing details for audience, remembering audience benefit and putting out speakers' own attitude in the audience' shoes are essential elements of successful speeches. Speakers should also think and anticipate what questions of audience will have and make sure that they can answer. Speakers should also take any of the audience' counter argument into consideration, having and making sure that they can rebut against those arguments with building case.

Pathos has consequent usage in political speeches and exerts an essential role in persuading audience. Pathos is directly linked with audience, the collective subject of speakers, on whom speakers try their best to impact by their own argumentation. In essence, a good knowing of audience' emotions is a good way to effectively utilize pathos, and therefore in rhetoric helps to enable speakers to act with words versus writing alone, to earn audience's credibility and faith. A successful speaker usually combines rational appeals with emotional appeals. Since speeches are a kind of persuasive activity, naturally they contain speakers' strong passions, such as love, hatred, happiness, and sorrow. It is just by taking all these emotions as activators, sometimes analyzing imperturbably, sometimes prompting enthusiastically, sometimes shouting with rage, and sometimes persuading with affection, that speakers produce the resonance in the audience and make them convinced. According to a psychological study, people tend to be dominated by their emotions at a critical moment. Therefore, to achieve the persuasive aim, on the basis of full analysis of the audience's psychology, 
speakers usually apply emotional appeal in their speeches to arouse the preconceived emotional reaction of the audience, such as sympathy, hatred, and desire.

Using words of enriched connotation is one of the commonly adopted methods to achieve such appeal. Connotative meaning gives words their intensity and emotional power. It arouses in listeners feelings of anger, pity, love, fear, friendship, nostalgia, greed, guilt, and the like. Speakers, like poets, often use connotation to enrich their meaning.

Terrorists neither listen to reason nor engage in reasoning with others. Their aim is to generate fear --- to frighten people into submission. They measure success by the magnitude of the fear they generate through brutal, savage acts of violence. Terrorists are prepared to kill to further whatever cause they claim to be pursuing. And the heinousness of these $\underline{\text { murders }}$ is accentuated by the fact that terrorist murder without passion. They murder with cool deliberation and deliberate planning. They are utterly amoral. (http://www.doc88.com/p-8781762355346.html)

The underlined words in the above passage have powerful connotations that are almost certain to produce a strong emotional revulsion to terrorism.

Here, in contrast, is another version of the same statement using some neutral words, which obviously has less power in stirring up the audience's emotions and rallying them to some cause.

Terrorists do not seek to negotiate with their opponents. They seek victory by using political and psychological pressure, including acts of violence that may endanger the lives of some people. To the terrorist, ultimate objectives are more important than the means used to achieve them.

Pathos can also be realized by using words of concrete meaning. The following address is delivered by President Reagan.

We stand on a lonely, windswept point on the northern shore of France. The air is soft, but 40 years ago at this moment, the air was dense with smoke and the cries of men, and the air was filled with the crack of rifle fire and the roar of canon.

When one Ranger fell, another would take his place. When one rope was cut, a Ranger would grab another and began to climb again. They climbed, shot back, and held their footing. (Ronald Reagan, 1984)

All these concrete words can make the audience produce visual, audio, and psychological associations, as if they were seeing and even experiencing the scene that regardless of the enemy's grenades and machineguns, the soldiers were intrepidly marching in the risk of losing their lives. Thus, the audience's emotions are aroused and speakers can better persuade people into their ways of thinking.

Another method of achieving such appeal is to use metrical language. The 44th American President John Kennedy in his inaugural address successfully uses emotional appeal to gain his persuasive aim: to pacificate the American people out of the fear of nuclear war and to show the government's determination to defend freedom and democracy.

In this inaugural address, Kennedy seldom uses rational appeal. Instead, he chooses to arouse the audience's emotions as much as possible. He appeals to Americans, "My fellow Americans, ask not what your country can do for you; ask what you can do for your country". Here, Kennedy uses this kind of repetition "ask not" and "ask what", to persuade his "fellow Americans" to devote themselves to the great cause of unification. When he said, "We observe today not a victory of party but a celebration of freedom", Kennedy moved all American audience, since the objects he was calling on were the Democrats together with all the other clans. In order to better claim the leading position of America, Kennedy did not hesitate a moment to call on the entire 
world. "Whether you are citizens of America or citizens of the world, ask of us the same high standards of strength and sacrifice which we ask of you".

To win understanding and support for the American policies, Kennedy also adopts different methods according to the different psychological needs of people all over the world. To the countries that were newly independent, such as India, he expresses his welcome to these "new states". But these countries have to "support their own freedom", instead of relying on America. To the countries that had the tendency to convert into socialism, he uses a metaphor, "those who foolishly sought power by riding the back of the tiger ended up inside", to arouse the audience's association so that he can gain his persuasive aim. To the countries that would make themselves America's adversaries, Kennedy speaks out of the American normal tough manners, "We offer not a pledge but a request". And then he appeals, "Both sides begin anew the quest for peace, before the dark powers of destruction unleashed by science engulf all humanity in planned or accidental self-destruction". On the one hand, by these words, Kennedy gives voice to his ethos; on the other hand, he evokes the rival force's dread of the nuclear destruction.

\section{Ethos as Persuasive Tactic in Speeches}

Ethical appeal (ethos) is directed to the audience's sense of what is right and proper. It is often used to urge people to support social causes, such as a cleaner environment, better race relations, equal rights for women, and aid to the disadvantaged. According to Aristotle, ethos can be categorized into the following three types: phronesis which means useful skills or wisdom, arete virtue which means goodwill, and eunoia which means goodwill towards the audience.

Violations of ethos include: speakers' direct interest in the outcome of the debate; speakers' vested interest or ulterior motive in the outcome of the debate; and speakers' lack of expertise. In a sense, ethos does not belong to the speaker but to the audience. It is the audience that determines whether speakers are high-ethos or low-ethos speakers.

Aristotle holds speaker "must not only try to make the argument of his speech demonstrative and worthy of believe, he must take his own character look right". For Aristotle, ethos employed by speakers can help to inspire trust in his audience. The more credible speakers are, the more likely audience will be persuaded.

In modern usage, ethos denotes the disposition, character, or fundamental values particular to a specific person, people, corporation, culture, or movement. For example, the poet and critic T. S. Eliot wrote in 1940 that "the general ethos of the people they have to govern determines the behavior of politicians" (Eliot, 1940, p. 25). Similarly, the historian Orlando Figes wrote in 1996 that in Soviet Russia of the 1920s "the ethos of the Communist party dominated every aspect of public life" (Figes, 1996, p. 682).

Ethos is for credibility. To building the credibility, speakers must show their expertise, image, and relationships in speeches with factual, specific, and reliable evidences. Speakers must make sure they are presenting a good argument. Narrating one's own past experience can help realize such appeal, too.

Demosthenes (384-322 BC), a born Greek speech impediment but later a prominent statesman and speaker of ancient Athens, argues that speakers can convince the audience by talking about their own past experience moderately. Al Gore adopts this persuasive tactic quite properly in his acceptance speech.

But, ladies and gentlemen, I want to tell you this straight from my heart; that experience changed me forever. When you have seen your six-year-old son fighting for his life, you realize that some things matter a lot more than winning. You lose patience with the lazy assumptions of so many in politics that we can always just muddle through. When you've seen 
your reflection in the empty stare of a boy waiting for the second breath of his life, you realize that we were not put here on earth to look out for our needs alone. We are part of something larger than ourselves. All of us are part of something much greater than we are capable of imagining. And my friends, if you look up for a moment from the rush of your daily lives, you will hear the quiet voices of your country crying out for help. You will see your reflection in the weary eyes of those who are losing hope in America. And you will see that our democracy is lying there, in the gutter, waiting for us to give it a second breath of life. (Gore, 1992)

By arousing the audience's sympathy, this statement successfully persuades the majority of the audience into convincing themselves that $\mathrm{Al}$ Gore has devoted himself to a higher life goal and that $\mathrm{Al}$ Gore has a wonderful moral promise towards politics.

Showing confidence in speeches can also strengthen ethical appeal. John Kennedy's inaugural address "The Torch Has Been Passed to a New Generation of Americans" is a typical example in successfully applying both emotional and ethical appeals. When Kennedy says in his speech "defending freedom in its hour of maximum danger", he makes his promise, "I do not shrink from this responsibility, I welcome it". This promise not only expresses his courage but also sets a good example, which can consequently ease people's fear towards the nuclear threat. "United, there is little we cannot do in a host of cooperative ventures. Divided, there is little we can do-for we dare not meet a powerful challenge at odds and split asunder". This is another famous sentence in his speech that impresses us deeply. By borrowing the famous words of Abraham Lincoln "United we stand, divided we fall", Kennedy not only shows his profound historical knowledge but also appeals the power of authority. The most successful point of Kennedy's applying of ethical appeals lies in his lofty stance in front of the enemies. Neither has he scolded, nor does he divide the war field, as if the common enemies of the whole human being were tyranny, poverty, disease, and war itself.

This shows that ethical appeal also has a powerful persuasive force even in logically structured, well-hanged together English political speeches.

An example of persuasion as discovering all rhetorical proofs used as persuasive tactics may be seen in President Clinton's address to the state union in 1996. To establish himself a sense of credibility, Bill Clinton intends to show himself a sensitive family man by delivering such words in his speech,

Before I go on, I would like to take just a moment to thank my own family, and to thank the person who has taught me more than anyone else over twenty-five years about the importance of families and children-a wonderful wife, a magnificent mother and a great First Lady. Thank you, Hillary. (Clinton, 1996)

With ethos of good name, Bill Clinton projects an impression to the audience that he is worth respecting and listening to. He also reminds the audience of the challenges children face by saying "I have heard Mrs. Gore say that it's hard to be a parent today, but it's even harder to be a child". Such words obviously create the identity between the audience and himself and cause not just to respond emotionally but to identify with his point of view, to feel what he feels. Besides, in this speech, Bill Clinton adopts logic argument to strengthen the persuasive power,

To the media, I say you should create movies and CDs and television shows you'd want your own children and grandchildren to enjoy. I call on Congress to pass the requirement for a V-chip in TV sets so that parents can screen out programs they believe are inappropriate for their children. When parents control what their young children see, that is not censorship; that is enabling parents to assume more personal responsibility for their children's upbringing. And I urge them to do it. (Clinton, 1996) 


\section{Conclusion}

Logos, ethos, and pathos have been applied in English political speeches. With their application, three appeals are devised to construct effective and powerful political message content. The three appeals are rational, emotional, and ethical appeals. And there are numerous methods to realize the three appeals, such as finding some persuasive examples, witnesses or data; applying some concrete, lively or rhymed language; citing some famous or authoritative words; or telling the speakers' own experiences. In order to achieve the best persuasive aim of speeches, speakers are required to nail down the aim of their speeches, to be familiar with the audience, to collect enough well-fitted materials, to arrange logic overall speeches, to choose proper speech style, and to master perfect speech skills.

\section{References}

Aristotle; Bizzell, Patricia; Herzberg, Bruce. (2001). On Rhetoric (Second ed.). New York: Bedford/St. Martin's.

Aristotle, \& Kennedy, G. A. (1991). Aristotle on rhetoric: A theory of civic discourse. New York: Oxford University Press.

Aristotle. (1990). Rhetoric. In P. P. Matsen, P. B. Rollinson, and M. Sousa (Eds.), Readings from classical rhetoric. Carbondale: Southern Illinois University Press.

Churchill, W. (1941). On the Nazi Invasion of the Soviet Union. April 19, 2019. Retrieved from https://wenku.baidu.com/view/77a9db8f84868762caaed5dd.html

Clinton, B. (Janu. 23, 1996). April 19, 2019. Retrieved from https://wenku.baidu.com/view/538c7f2ded630b1c59eeb56d.html

Eliot, T. S. (1940). The idea of a Christian society. New York: Harcourt Brace.

Figes, O. (1996). A people's tragedy: The Russian Revolution, 1891-1924. New York: Viking.

Gore, A. (July 17, 1992). "In Their Own Words; Excerpts From Speech By Gore at Convention". The New York Times. Retrieved June 30, 2010.

Herrick, J. A. (1997). The history and theory of rhetoric. Boston: Pearson Education Company.

Reagan, R. (1984). 40th Anniversary of D-Day. April 19, 2019. Retrieved from https://www.docin.com/p-2098588942.html

Timmerman, D. M., \& Schiappa, E. (2010). Classical Greek rhetorical theory and the disciplining of discourse. London: Cambridge University Press.

Wardy, R. (1996). Mighty is the truth and it shall prevail? In A. Rorty (Ed.), Essays on Aristotle's rhetoric. Princeton: University of California Press. 